\title{
The Impact of Network Readiness Index and Good Governance on the Tourism Industry Revenues in Selected Countries of Southwest Asia: With System Generalized Method of Moments
}

\author{
Seyyed Mohammad Ghaem Zabihi ${ }^{1}$, Mahmood Hoshmand ${ }^{2, *}$, Narges Salehnia ${ }^{3}$ \\ ${ }^{1}$ MSC student of Economics, Ferdowsi University of Mashhad, Mashhad, Iran \\ ${ }^{2}$ Professor of Economics, Ferdowsi University of Mashhad, Mashhad, Iran \\ ${ }^{3}$ Assistant Professor of Economics, Ferdowsi University of Mashhad, Mashhad, \\ Iran \\ ${ }^{1}$ Smq.Zabihi@mail.um.ac.ir, ${ }^{2}$ M-Hoshmand@um.ac.ir, ${ }^{3}$ N.Salehnia@um.ac.ir
}

\begin{abstract}
As we know, the economy of science is to achieve optimal gains using scarce resources. Similarly, a problem where economies of the world are trying to resolve it is the issue of how to achieve an optimal economic contribution from limited tourism resources. According to the fact that global studies and statistics indicate that good governance is considered as the most important factor in developing countries and is considered as a strong governance of the development and as Information and Communication Technology (ICT) is effective in the interactions and economic and social exchanges of any society, it is the link between the tourism industry and the technology under the form of a robust tool and utilitarian in the tourism process called E-tourism can play a significant role. Therefore, the aim of this study was to investigate the effect of network Readiness Index and good governance on income from tourism industry. In this study, data and information about 14 selected countries were collected from Southwest Asia in the annual period of 2016-2011 in the form of panel data and the proposed model was used and estimated by the generalized torques system method. The estimated results of the model indicate that both hypotheses have a positive and significant impact on the amount of Network Readiness Index in the income of tourism industry, as well as the positive and significant effect of the index the amount of income from the tourism industry is confirmed, and their impact has been positive and significant, as well as exchange rate variables, revenue and commercial openness, also have a positive and significant effect on revenues of the tourism industry.
\end{abstract}

Keywords: Information and Communication Technology, Digital Economy, Electronic Tourism, Principle Factors Analysis, Dynamic Panel Data.

Classification of JEL: L86, L63, L83, L63, O47, C23, C15, C26.

\footnotetext{
* Corresponding Author
} 


\section{Introduction}

New age to the age of information and communication or Internet of Every Thing is well known. In general, the last century within itself has a variety of strange things, so that in time and place and has reached a point and the promise of a global village is formed. In the meantime, according to the theory of Joseph Schumpeter (1934), stimulates the growth and development of the economy, the invention of new goods, new markets, etc., and most importantly, technology as driving the economic growth and development.

For the correct perception of the process in which the world is being around, as well as technology applications in the science of economics, we must investigate the concept of digital transformation in the economy leading to the term of the digital economy. In fact, digital economy includes all social and economic activities that the telecommunication network by on various software and is done with the use of big data, addressed. Statistical estimate of Cisco's expression that 14 trillion dollars, worth opportunities that the digital transformation in the next five years will be created in the world (Poon, 1993; Suomi and li, 2010; Martin, 2004).

But on the other hand, during recent decades of good governance as a hot topic in the management of the public sector, and this is an important role for the government in the health of the community. Studies and global statistics indicate that good governance is one of the most important factors in developing countries has been considered as a solid framework of good governance and the development of the title. This term is defined by the European Union such that good governance is transparent and accountable management: in the country with the aim is to ensure a fair and sustainable economic and social development (Barnard, 2007; Blake et al., 2006).

Researchers with different approaches (process, liberal and socialist), various dimensions (political, economic and etc.,) And multiple goals (economic development, political and human sustainable development), the key to good governance. Over the past two decades, economic, social and political researchers and scientists from the various narratives that have presented each of this approach, in turn, features and aspects of good governance and explaining. On the other hand, some scholars have expressed a wider definition of sovereignty, from the point of view, governance is a process that collectively the problems of society and also the needs of the community. According to this view, the evidence available, the government is not only the government, but groups and individuals, the private sector and civil society are involved and also this topic includes systems, procedures and are in the process of planning, management and decision making is also involved (Bovarid,2007).

On the other hand, today, the issue of tourism is one of the attractive and discussed issues become professors, students and researchers. According to the statistics published by the World Tourism Organization, in 2017, a total of a billion and 323 million tourists were left to visit the destinations of other countries in the Territory; The statistics have increased by about $6 \%$ for the year 2018, and a billion and 400 million people reported and with the forecasts made this important in 2030 to a billion and 800 million tourists around the world will arrive (Aldebert et al., 2011; UNCTAD, 2004; Altin and uysal, 2011).

Tourism industry is one of the economic sectors that can be raised as a clean industry and increases currency revenues and plays a worthy contribution in improving employment and income (Alexander Leitao, 2010; coopers, 2005; Hipp and Grupp, 2005). The industry is as industrial as an industry that and the domestic industries to the front, because the increase in the arrival of tourists leads to work in the aircraft, work in the hotel, English language training, work at the travel agency, Department of Foreign Affairs, photography, tour guides, transportation, insurance, handicrafts, etc. Therefore, it is important that this category is very useful for countries that have faced an unemployment problem. Today, the industry has a prominent role in the global economy and the majority of the world's countries are looking to increase their share of the tourism market.

Thus, according to the supernatural theory, through the digital economy and the attention and promotion of the network Readiness index, this variable is very necessary and 
important to the presence of an effective tool called e-tourism in the tourism industry pay special attention. We may, by relying on lessons from the results of successful countries in the field of tourism industry, including the successful climate, both adjacent and Asian, by this fundamental stimulus, as well as by the institution of governance every country in the path of growth and prosperity of the society can be effective, we are looking at this research to have the effect of network Readiness Index and good governance (as well as its subeach) on income (Gruescu et al., 2009; Marcussen, 1999; peppaard, 1993; Werthner and Klein, 1999). Explore the tourism industry in selected South Western Asia and analyze the results. It is possible to direct the Iranian economy from the single-product side to highincome tourism industry and use electronic tourism to supplement the tourism industry as well as the Iranian economy towards economic growth and development and achieving sustainable development goals of ability steps. Given the above, this study using econometrics approach and using dynamic Panel Data approach, experimental work at the same time as the network readiness index and good governance on the amount of revenues from the tourism industry in 14 countries of Southwest Asia during the years 2011-2016.

More of the most relevant studies have been paid in the field of study. Maritime et al. (2012), in research, it is important that good governance is one of the most important factors in developing countries. Considering the importance of tourism in the country's economy, in this study, using panel data methods, the effect of good governance index, GDP growth, technology growth, inflation rate and the state of educational costs on the development of tourism industry in 30 selected countries in developing and the OECD countries in an annual period of 1996 to 2009, is. The results of this research indicate that both of the countries have had a positive impact on the economic growth and technology level and the level of education in the OECD countries has been positively influenced and returned in developing countries. As well as the six sub-indicators of governance, which have been expressed in the form of good Governance index in this study, have a positive and significant effect in both groups of studied countries.

MamiPur and Nazari (2014), in an article entitled to the amount of tourism development in economic growth in Iranian provinces, estimates of tourism impacts on economic growth of Provinces of Iran 2000 to 2010. Data panel method was used in econometrics to estimate this important. This research has shown that there is a positive relationship between tourism and economic growth in Iranian provinces. It also proves that for every ten percent increase in tourism use, a percentage of GDP increases per capita. Other results of this study are: a positive relationship between human and physical capital and negative relationship between the unemployment rate and Consumer price index (CPI), with economic growth achieved. Leitao (2015), has carried out a research in a period of 2004 to 2013 for Orange country. In this study, the econometrics methods have been used for analyzing the results and estimating the corresponding model. In addition, the tests of the root unit and the Dynamic panel (SGMM) have been used in this research. Considering the estimation and estimation of the model by dynamic panel method, relative prices, per capita income, human capital and government costs have been effective on international tourism demand in orange, and these variables encourage international tourism demand in oranges.

Ghulam Ali et al. (2018), in his study, using the structural reversal model (SVAR), we seek to investigate the shocks in the macro economy on the incomes of tourism industry in Malaysia, followed by its investigation in the years 2001 to 2012 the economy of this country, what behaviors have to do with the shock of changing oil prices, exchange rates, changes in prices, export, economic growth and tourism revenues of self-show. The results of this study indicate that oil price shocks, economic growth, exchange rate and export have a reverse impact on tourism revenues, except for consumer price index which has shown a positive impact in this research.

Shamaei and Yousefi (2018), in research, the role of good governance of sustainable tourism revenues (file: Masjed Soleyman City) have been. The method of this research is survey-exploratory and according to the data of the research type is quantitative and qualitative and the method of access to data is based on documentary and survey. The study population is 30 urban specialists and the method is selective and purposeful sampling. In 
order to analyze the data, inferential statistics (T-Test) were used in SPSS software and also for weighting of variables considered by multi-criteria decision-making models, ANP and Super Vendim software were used. The findings indicate that among the variables of good urban governance that influence sustainable urban income, the indices of equipping the infrastructure and facilities for attracting private investments in tourism have the highest weight and the equality index of all stakeholders against the benefits and programs of tourism development has the lowest weight.

Boga and Erkisi (2019), have shown a short-term relationship between tourism revenues and economic growth in research. This study included 483 data in an annual period of 1995 to 2017 for 21 Asian and Pacific countries. A double-sided result can be seen in this study: 1) a percentage increase in economic growth increases the amount of tourism revenues of $1.9 \%$ in the long run, and vice versa and 2) the income of the economy influences the economic growth, and with each increase in tourism revenues, economic growth increases to $0.49 \%$ in long-term and vice versa. Also, a hypothesis related to bilateral relationship between tourism revenues and economic growth is confirmed.

\section{Literature review}

First of all, The countries were also selected from developing countries selected in Southwest Asia, and based on the available data based on the study population, out of 22 countries, 14 selected countries ${ }^{1}$ were finally selected. The most important reason for choosing this set of countries was due to its close geographical and climatic location and the exchanges and exchanges they had with Iran. In this study, Stata software will be used to make the necessary estimates and estimates. (Fig. 1) shows the countries studied.

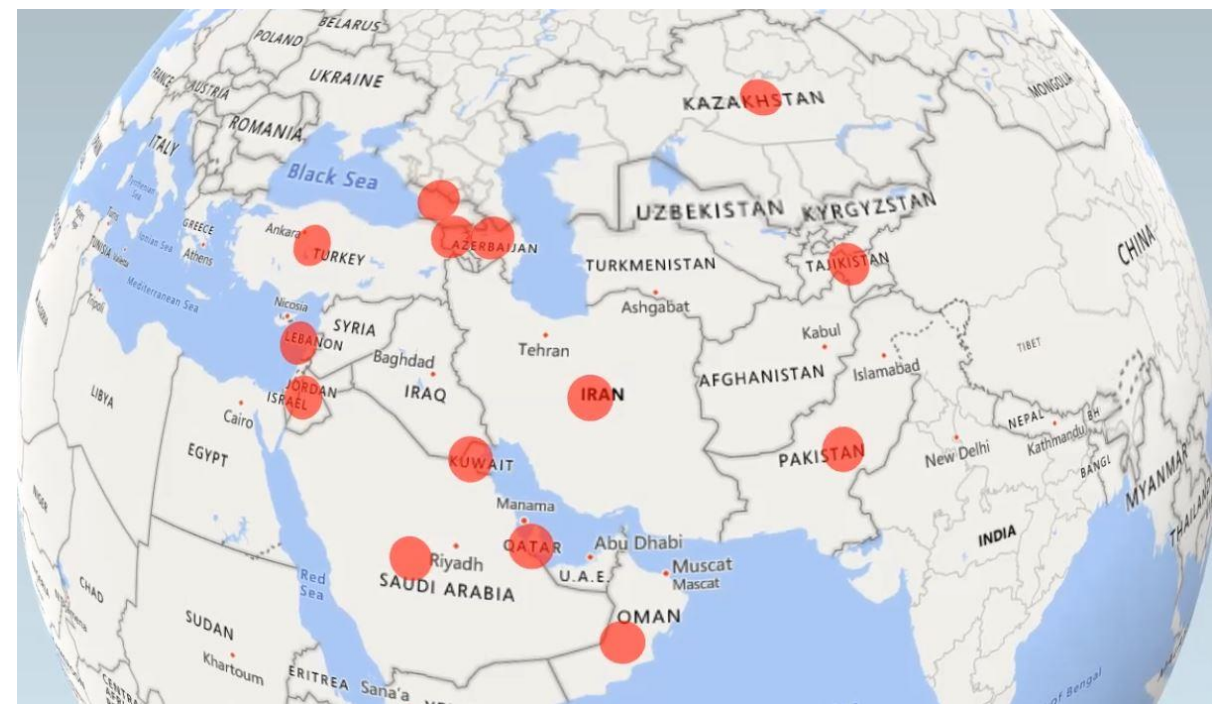

Fig. 1. The studied countries in Research

In the continue, the theoretical foundations of this study and then the foundations of the network and the relevance of these two important issues, has been extracted to the hypothesis. The factors that affect the process of income from tourism and the entry of tourists and how to distribute it around the world are evaluated and inferred from the basis of basic trading theories at the international level. A comprehensive economic study of the tourism industry's determinant factors is a method that is based on theoretical theories, and this is what the empirical studies are approved. To achieve this important, economic

${ }^{1}$ In this study, due to the limitations and lack of statistics and information of some countries, finally 14 countries studied in this study are: "Iran, Armenia, Azerbaijan, Georgia, Jordan, Kazakhstan, Kuwait, Lebanon, Oman, Pakistan, Qatar, Saudi Arabia, Tajikistan and Turkey”. 
theories such as the specialized theory of international affairs are very important. On this basis, four theories I have determined the position of a country in the international tourism calculate can be thought of: 1) Theory of Divine Gift, 2) relative cost theory, 3) Theory of absolute advantage and technical knowledge, 4) Theory of demand requirements. There are various theories about tourism and its influential factors (Irvine and Anderson, 2008; Tahayori and Moharrer, 2008). Each of these theories has come to this issue from one or more.

\subsection{The Theory of Divine Gifts (abundance of natural resources) and international tourism}

The frequency of natural resources in the year 1919 was raised by a "Heckscher" and later in the year 1933 by "Ohlin" and expanded. According to this theory, this argument can be found that countries with very large amounts of capital, must issue a group of goods that are capital, and at the opposite point, the group must enter the goods that are the user. This theory is true for natural resources that are very important in international tourism topics. Because many tourism facilities are benefiting from the relative advantage of natural resources. In fact, the divine gift can be named as sources or factors that guarantee the production of goods and services in international tourism. Due to this, it can be found that the abundance of natural resources can have a high impact on the international tourism situation in each country (Xiaoqiu et al., 2003). Of these gifts and the blessings of the, can be learned as potential to animate the economic and tourism cycles. The resources in the divine gifts can be divided into three distinct categories, that's show in (Fig. 2).

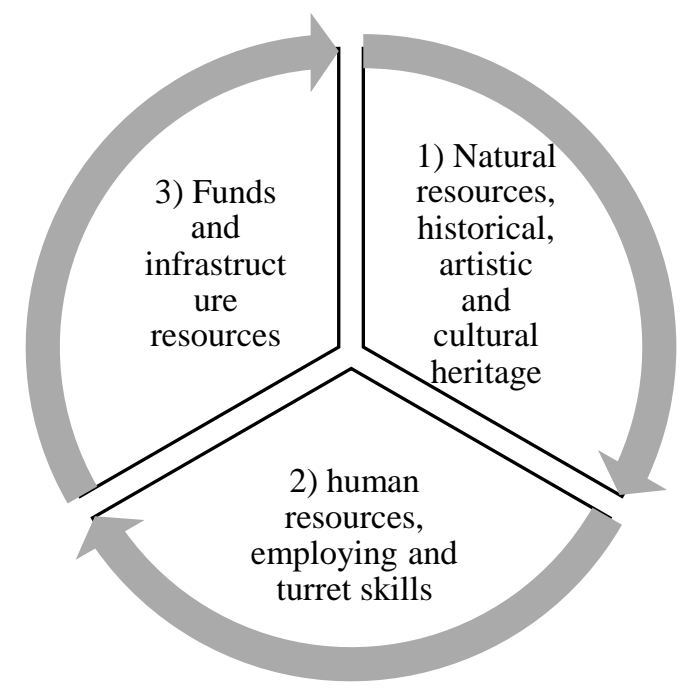

Source: Xiaoqiu et al., 2003

Fig. 2. The resources in theory of divine Gifts

\subsection{Network Readiness Index and tourism industry}

One of the fundamental and influential factors in the tourism industry is the level of technology in countries. Today we are entering an era in the world where the Internet is taking everything, and still $99 \%$ of the objects in this planet are not connected to the Internet (The Report of Ict from World Economic Fourm Report, 2013). According to prediction from Mac Kinsey to 2025, the economic radiation caused by the synergy and convergence of the internet will be between 7.2 to 2.6 trillion dollars (Global Telecommunication Union Report, 2013:17-18). Previous studies and theories and concepts of the present claim that information and communication technology with increasing the individual, public and private efficiency and the reduction of the costs of active enterprises in the field of tourism, in the existing processes and in particular the revenues of tourism industry are very unique. 
In past studies, it is more emphasized on the use of succession for ICT process, and from the Internet, the number of Internet users, the number of users of fixed lines, and the penetration rate of mobile phone.

However, the fundamental issue of these studies is that only as it is applied and communication technology has been studied and the other important factors such as the environment and the level of the players ' readiness are not considered as effective variables. The network Readiness Index is the first attempt to construct a conceptual model for measuring the complex reality of information and communication technology. This indicator measures the factors affecting the countries ' power in efficient utilization of the technology. The main purpose of this index is to provide guidelines to politicians and policymakers in the country's development path about the effective use of this technology (UNWTO, 2011; Xiaoqiu et al., 2003). Based on this indicator, the impact of information and communication technology is not only limited to the use of information technology and also depends on environment and readiness indicators, For each of these two can be selected based on the following cases, mention that in this research is addressing one of the most important and fundamental index below this index and not just for the necessity and summarized in (Table.1) and paragraph it is mentioned.

Table. 1. Conditions of environment indicators and readiness

\begin{tabular}{|l|}
\hline 1) Conditions of environment \\
\hline - Market conditions, \\
- Regulatory structures, \\
- Conditions that are susceptible to attract \\
innovation and entrepreneurship; \\
\end{tabular}

\begin{tabular}{|l|}
\hline \multicolumn{1}{|c|}{ 2) Preparation conditions } \\
\hline - Hardware infrastructure, \\
- The level of skill required to use ICT in \\
three levels of individual, board and \\
government, \\
- Material ability (affordability) in using \\
ICT services;
\end{tabular}

Resource: ICT Report World Economy Association, 2013: 5.

In summary, in the sub-index of the nurture environment that facilitates the market position and the legal framework of a State of entrepreneurship, innovation and development, through ICT and communication technology. This important sub-index includes two pillars of the political and legal environment and the Environment of innovation and business. But under the readiness index, the nurture that a country is under construction and other factors to support the promotion of information and communication technology, and this also includes three pillars of the infrastructure, the ability to pay and skills. The following two indicators also shine in calculating the network Readiness Index, which include: The sub-index of application, which measures the use of information and communication technology by the main stakeholders of society: the Government, business and individuals, and the fourth sub-index, the impact that the two pillars of economic impact and social impact and the vast socio-economic impacts that arise from ICT. The rate range of the network Readiness index is ranked between 1 (weakest) to 7 (the strongest) since 2011.

Therefore, according to the topics discussed, the importance of attention to international tourism through four of these theories in the superiors has been harvested in Venice BAATF to the opinions of experts and global reports of today's use of a network readiness index, for a scale to measure electronic tourism, very realistic and necessary. It can be acknowledged that the Buhalis (2003) is the e-tourism of this definition, making all the process and value cycles in tourism, travel, hospitality with the help of industries that increase the efficiency and ability of the organizations, where ICT contributes to the tourism business in making communication easier with consumers. In other similar definitions that have been defined in the context of the European Union's citizenship program, e-tourism in 
connection with the application of Internet technology in the management of tourism activities are determined (Zhou, 2004; Gratzer et al., 2004).

In fact, ET, the electronic presentation of all those services that have traditionally benefited from tourists in the past, is a service that has been made possible for dramatic advances in areas such as information and communication technology. On the other hand, electronic tourism covers all business components and processes such as e-commerce, research and development of electronics, content production and provision of various services in the form of electronics in cyberspace or communication. Also, in other words, e-tourism is a collection of Web sites (public and private) and special protocols that are used to generate and redistribute information in various formats, including text, image, catalogues and brochures, advertising risers and even services such as hotel reservations and accommodation complexes and new discussions such as electronic shopping (Mighetti and Buhalis, 2010; Kuttainnen and Lexhang, 2012).

On the other side, the theoretical aspects of the governance and the theoretical aspects of economic factors in tourism are discussed. Considering that tourism is a polyhedral activity that covers various economic, social and other competent groups, the path of sustainable development requires a strong governance system. Therefore, governance in the development of tourism has been more important in recent years, because directly and indirectly determines the parameters that tourism is occurring as an activity, and it affects the development outcomes of tourism (Cornelissen, 2005; Cox et al., 2009).

The government is one of the most important elements of tourism management, both in the national field (through tourism policy) and an international level (as a participant in global regulatory regimes), but it remains a respects. Shaw and Williams in 2004 AD have identified several means through which the State is the main regulatory agent. This is a major point that has been associated with the global economies, and involves creating a framework in which firms operate with others and can occur during that international movement. The Government also contributes to the formation of a legal and policy framework (through legislation or political purposes) in which tourism activities are occurring, in the form of tourism production and consumption. In the year 2000, the Hall (2010) also pointed out that tourism is a very important political issue. This important connects different layers of governance, and most importantly, it needs coordination and development at all levels. So, by turning to the supernatural theories and discussions, it is possible to conclude that governance has a significant impact on the tourism industry. If a good governance in the economy of any country, especially the Iranian economy, has been resonating correctly and systematically, it is possible to achieve a favorable result that the meaning of tourism development and the amount of income gained from this industry is large and important (Gomis and et al., 2012; Mupfia, 2015).

So in general, it is important that the focus of attention to the high revenues of tourism industry and through the tools of the day and efficiency such as e-tourism and it is the movement of digital economy within the country's economic system has paid special attention. And this should not be neglected by the prominent role of governance in every society (Stiakakis and Georgiadis, 2011; Byrd and Marshall, 1997). Therefore, by turning to the opinions and topics raised above and as well as considering the importance of tourism and information technology and communication in the advancement of any society, the hypotheses of the "Network Readiness Index" on the amount of income gained from the tourism industry has a positive and meaningful impact, and the index of good governance on the income of the tourism industry has a positive and meaningful effect.

\section{Model, Data and Methodology}

In this study, in order to evaluate the effect of network Readiness Index (scale for electronic tourism assessment) on the amount of income from the tourism industry, using dynamic panel data technique and extended system torque method for 14 selected countries of Southwest Asia during the period of 2011 to 2016 was used. Econometric patterns with 
dynamic relationships are characterized by the entry of interruptions or interruptions of the dependent variable as an explanatory variable (the right parameters of the model). The generalized Torques method was first described by Hansen (1982), which provides an easyto-find estimate of the efficiency of the estimates. This method covers dynamic effects of dependent variables. If the variable depends on the values associated with the interrupt, it will result in a correlation between the explanatory variables and the disturbing sentences (wastes), which will show the results of the conventional minimum method and incompatibility. The generalized Torques method can be used to use the variable variables.

However, since in a dynamic panel data model, the gap between the dependent variable, such as disturbing the correlation, is used as a tool for the second interruption of the dependent variable and the interruptions of other variables (within the framework of a recursive form) as a means of interruption of dependent variable based on generalized method of moment. The estimated female (GMM), which was proposed by Arlano and Band (1991), is essentially a difference from the existing pattern in order to rid the problem of specific effects related to the sections (individuals) and all the fixed rgars of time. Also, in this method, to eliminate the correlation between the gap and the error sentence, the interruption of variables as a tool for female estimates, the extended two-step system is applied. The estimation of a two-step woman in a free manner is more efficient and effective if there is an inconsistency variance of the error component. Torque conditions use the conditional mode between the error errors and the intermittent values of the dependent variable. In this process, it is assumed that the main disruptions are not serial correlations. In which the method and test of Arlano and Band are used for serial correlation test in disturbances. In this model, the Sargan test is used to test the over-identification constraints to examine the validity of instrumental variables (Baltaji, 2005).

Given that our dependent variable in this study is income, and since we know that tourism revenue affects its own years before and after (for example, this year 1,000 tourists visited a tourist spot). Therefore, part of the income earned from these people in this tourist spot will be spent on reconstruction and promotion, etc., and this will lead to the development of this building and increase its facilities), thus attracting more tourists in the coming years. It attracts and attracts and will increase tourism revenues in those years. For this reason, it can be relied on that for these variables from the selected countries, the generalized torque method can be used to assess the impact of each of them on the revenue generated by the tourism industry. However, the data of this study have been extracted from the World Bank website, the Global Development Index database and the Global Governance Index database.

Inspired by the theoretical foundations and experimental studies of Boga and Erkisi (2019), Leitao (2015) and Daryaei et al. (2012), as well as the pattern of panel data introduced and used by Baltaji (2005), the equation for the study The impact of a good governance index on tourism industry revenues in selected Southwest Asian countries is as follows:

$(\mathrm{TR})_{\mathrm{it}}=\beta_{0 \mathrm{i}}+\gamma(\mathrm{TR})_{\mathrm{i}(\mathrm{t}-1)}+\beta_{1}(\mathrm{NRI})_{\mathrm{it}}+\beta_{2}(\mathrm{GGI})_{\mathrm{it}}+\beta_{3}(\mathrm{OER})_{\mathrm{i}(\mathrm{t}-1)}+\beta_{4}(\mathrm{GDPP})_{\mathrm{it}}+\beta_{5}(\mathrm{TP})_{\mathrm{it}}+$ $\beta_{6}(\mathrm{TO})_{\text {it }}+\mathrm{U}_{\text {it }}$

In relation to the number (1), $\mathrm{Uit}=\mu \mathrm{i}+\lambda \mathrm{i}+\mathrm{vit}$, in which $\mu \mathrm{i}$ represents the specific effects of the country and $\lambda i$ represents the specific effect of the year In the following, we will describe in more detail each of these cases.

\subsection{Definitions and sources of variables}

The information sources and the definition of each of the variables of the model are summarized in (Table. 2).

Table. 2. Variables used in the model, short definitions and statistical sources 


\begin{tabular}{|c|c|c|}
\hline Variables & Definition & Source \\
\hline $\operatorname{Ln}(\mathrm{TR})$ & $\begin{array}{l}\text { Natural logarithm of the income of the tourism } \\
\text { industry (in billion US dollars) }\end{array}$ & World Bank \\
\hline NRI & Network readiness index & $\begin{array}{l}\text { World Economic } \\
\text { Forum } \\
\text { Global }\end{array}$ \\
\hline GGI & Good governance index ${ }^{1}$ & $\begin{array}{l}\text { Governance } \\
\text { Indicators }\end{array}$ \\
\hline OER & Official exchange rate (in US dollars) & World Bank \\
\hline $\operatorname{Ln}(\mathrm{GDPP})$ & $\begin{array}{c}\text { Natural logarithm of real GDP per capita based on } \\
\text { purchasing power }\end{array}$ & World Bank \\
\hline $\operatorname{Ln}(\mathrm{TP})$ & $\begin{array}{l}\text { Natural logarithm of the ratio of the number of } \\
\text { tourists entering the country to the population of } \\
\text { that country in the year } t\end{array}$ & World Bank \\
\hline $\operatorname{Ln}(\mathrm{TO})$ & The natural logarithm of Trade openness ${ }^{2}$ & World Bank \\
\hline
\end{tabular}

Resource: Research Findings

\subsection{Explanatory variables used in the model}

First, it is important to note that tourism revenue (TR), following the studies of Boga and Erkisi (2019), Panic (2015), and Cho (2010), in order to maintain the tourism industry's breadth of tourist income index between -International (in US dollars) is used as the dependent variable.

- The Network Readiness Index: This index will evaluate and assess the readiness of countries to exploit the opportunities created through ICT in annual sections. The aforementioned indicators are seeking to make a better understanding of the impact of fava on the competitiveness of the nations, not only as a particular industry, but also as a motordriving industry as the main platform for any economic movement. One of the most important things that this indicator has for us is to consider the sub-indicators of the environment and readiness to use (individuals, Governments and firms) of ICT, which are briefly discussed in the theoretical foundations and are expected to have a positive effect on the amount of income gained from the tourism industry.

- Good Governance Index (GGI): There are several definitions for this. The Organization for Economic Cooperation and Development (OECD) defines good governance as the ability to work with different environments to achieve equilibrium at various local and international levels, and on the other hand, Lyon defines good governance as: Managing the effectiveness of a country's economic and social resources. Such that management is transparent, accountable, fair and open (Lyons, 2000). According to the World Bank's metrics for this indicator, this is important with six important and influential sub-indicators: 1) the right to speak and respond; 2) political stability; 3) government efficiency and effectiveness; The quality of legislation; 5) The rule of law and 6) The control of corruption is assessed and evaluated for each country. In this study, we have transformed these six sub-indices into a final index called Good Governance thanks to the existing statistical methods, and according to theoretical foundations as well as past studies including for ex. Daryaei et al. (2012) expect the positive and significant impact of this variable on the

1 The combination of six main indices of governance introduced by the World Bank has been achieved by SPSS software analysis with Principle Factors Analysis technique. the results of this approach show on the Appedix.

2 This has been calculated from the total export and import ratio to GDP (at a fixed price of US \$2010). 
amount of revenue from the tourism industry. Following are the explanatory variables of control that are placed alongside the good governance variable, which are extracted from previous studies and reviewed and introduced.

- The official exchange rate (OER): In any amount that the official exchange rate is higher, the competitiveness of domestic products and services is cheaper than foreign products and it will be more. It is important for tourists, and hence, the cost of living in the country is effective than the country of origin and the official exchange rate on travel motivation. So the effective variable in the process of this study is the exchange rate, which is also visible from within theoretical foundations and most of previous studies. It is worth noting that this variable has entered into a model of a difference.

- Per capita income (GDPP): Revenue of the country of origin is one of the most important variables affecting tourism in the destination country. In other ways, since tourism is usually considered as normal or luxurious commodity, this variable is more sensitive to the income level and is referred to as one of the most important and decisive variables in the tourism revenue equation. In this study, the actual revenue variable was used based on purchasing power. In most studies, the variable of GDP per capita was very effective in controlling variables.

- Trade openness (To): This is one of the most important principles in assessing and measuring the development of a country's economy, calculated from the sum of total exports and imports to GDP. So that the more a country's borders are open for exporters and importers, the larger the deduction, that is to say, that country and its economy have a more open and free trade degree. According to previous studies, such as Boga and Erkisi (2019), this variable can be considered as other important and influential variables on tourism revenues.

In addition, one should not forget that tourism is affected by natural shocks, war, policy changes, tastes, propaganda, expectations, political instability, terrorism and other special events. Given that the data for the cases mentioned are not available, the cases are entered into the model as a disruption or error statement and are tested.

\section{Discussion and results}

In order to obtain a non-false estimation between the model variables, the variables in the regression must be static or combine to be static. If the data used in a study are nonstationary, the results of the estimates will lead us to a false regression. But for panel data resilience test, this study, considering the years studied (due to geographical and statistical constraints), is six years, and with reference to the concepts in the Baltic book, panel data for below 15 years is not needed (Baltaji, 2005).

But in the following, the results of estimating the effects of network readiness index variables as the main explanatory variables and other control variables on the level of tourism revenues (corresponding to model number (1) ), using dynamic panel data method (SGMM approach) in (Table. 3) is displayed. The results of the model show that all coefficients extracted at error level less than $5 \%$ were significant and all of these coefficients had positive and significant effect.

Table. 3. Results of Estimation of the Model by Two-Step GMM

\begin{tabular}{cccc}
\hline variables & Coefficients & Z statistic value & Probably value \\
NRI & 0.033 & 2.13 & 1.345 \\
GGI & 0.035 & 2.11 & 0.464 \\
OER & 0.000 & 4.90 & 0.0005 \\
Ln (GDPP) & 0.000 & 4.70 & 2.722 \\
Ln (TP) & 0.014 & 2.45 & 0.239 \\
Ln (TO) & 0.020 & 2.33 & 0.249
\end{tabular}




\begin{tabular}{|c|c|c|c|}
\hline Cons & 0.000 & -4.35 & -71.758 \\
\hline Sargan & & $9.488^{*}(0.735)^{* *}$ & \\
\hline $\mathrm{M}_{1}$ & & $0.824(0.410)$ & \\
\hline $\mathrm{M}_{2}$ & & $-1.191(0.234)$ & \\
\hline Wald & & $14163(0.000)$ & \\
\hline
\end{tabular}

According to the results of the (Table. 3) significant, based on the results of this test, the hypothesis of zero (which is based on the specific equation) will not be rejected and therefore the variables used by the means in the model estimates are of the necessary credentials (there is no connection between the disturbing components and variables of the tools handled), so therefore, the use of tools variables to control the correlation between explanatory variables and equation of disorder The pattern is considered essential. Also, the results of self-solidarity among (Table. 3) disturbing sentences indicate that there is no significant correlation between the 5\% and the second rank self-correlation, and the unexpected estimates are the compatibility characteristics. The interpretation and analysis of the results of the mentioned model is one place in the classification of this season.

The following findings (with 95\% confidence level) can be deduced from the results of (Table. 3):

$\checkmark$ The estimated coefficient of network Readiness Index as one of the most important variables in this study on the amount of income from the tourism industry has a positive and significant effect with this interpretation that, with a percentage increase in the rate of network Readiness Index, the tourism revenues increased by a rate of $1.344 \%$. This is a very important finding on the only hypothesis in this study of the Image Action Society and the result of the theoretical foundations and empirical studies, especially Buhalis and Deimezi (2004).

$\checkmark$ The estimated coefficient of good governance index as one of the most important variables in this study on the amount of income gained from the tourism industry has a positive and significant effect with this interpretation, with a percentage increase in the rate of good governance of tourism revenues increased by $0.465 \%$.

$\checkmark$ The estimated coefficient of official exchange rate on incomes from the tourism industry had a positive and significant effect with the interpretation that, with a percentage of increase in the rate of official exchange rate of tourism revenues increased to $0.0005 \%$. This important is consistent with the results of the studies of Ghulam Ali et al. (2018).

$\checkmark$ Estimated revenue coefficients have a positive and significant effect on tourism revenues, so that, for a percentage of increase in this variable, the amount of tourism revenues increased by $2.722 \%$, thus improving the income status of countries is one of the factors influencing the amount of income from tourism, which is consistent with the results of Leitao (2015).

$\checkmark$ The estimated coefficient of the number of incoming tourists to the destination country was also positive and significant, so that with a percentage increase in this variable, the amount of revenues from the tourism industry increased by a rate of $0.238 \%$, which is also consistent with the results of previous studies.

$\checkmark$ The estimated coefficient of the trade is also positive and significant, with a percentage increase in this variable, the amount of income gained from the tourism industry increases to $0.249 \%$. The result is also a step with a study of Boga and Erkisi (2019).

In the end, we also need to mention that the test parent statistic to test whether the parameter estimated by the sample is equal to the desired parameter or not, and sometimes instead of the test T., with the value of statistic of 14163 and the probability level of zero percent error was obtained for estimating the model, which assumes zero of the test which is based on the ineffective variables in the regression model.

\section{Conclusion}


The economy means acquiring optimal gains using scarce resources. No matter what person is looking for is the spiritual benefits of travel, the business is offering goods and services to tourists, or the host State to tourism, constitutes the economic benefit of tourists spending, it is important that the general rule is the same in all of these. Economic brokers seek to supply limited resources of tourism (physical and financial) and meet the demands of tourists. Demands the results of physical and functional needs (usually limited) and intellectual demands (which are almost limited). Similarly, the notably that economies are trying to resolve is how to achieve an optimal economic share of limited resources of tourism, while they are faced with constantly changing demands (whose physical needs and psychic desires are created).

The present study uses a dynamic panel data approach and a two-stage generalized torques approach to investigate the effect of good governance on the amount of income gained from the tourism industry in selected Southwest Asian countries during the period of 2011 to 2016. Since according to theories of internal and external researchers, good governance is one of the main components of attracting foreign tourists, the findings of this study also have a significant positive impact on the quality of good governance on foreign tourists. The index of good governance, which is derived from the six sub-index of governance provided by the World Bank, has a positive and significant effect on the amount of income gained from the tourism industry in the selected countries of South Western Asia. The results of this study show that, the two hypotheses of this research, which have a positive and significant impact on the network Readiness index on the amount of revenues from the tourism industry, and the positive impact of good governance index on the amount of income gained from the tourism industry, have been confirmed.

According to the results, it can be stated that the first step in achieving the field of information and communication technology is the use of appropriate infrastructure, which is the general component of its identification, electronic readiness. Among the countries of the study, Iran in the recent decades have been in the field of public and government use of ICT, but in the fields of communication and information networks infrastructure (including: Internet penetration rate, mobile penetration coefficient, bandwidth and cell phone coverage), the amount of access to digital content and the amount of individual and commercial use is still in advance.

In general, for the present study, the following results can be thought: 1) The network Readiness Index, which is the main index of our research model and also the criterion for electronic tourism assessment can be mentioned, has increased revenues from the tourism industry; 2) good governance Index, which is the other main index of our research model, has increased revenues from the tourism industry; 3) exchange rate in the studied countries with a time lapse period is effective on the amount of income gained by the tourism industry; 4) The coefficient of GDP per capita compared to other estimates has been more impressive on the amount of income gained by the tourism industry; 5) The ratio of the number of tourists to enter the population of host country, positive and mandar but small; 6) The degree of commercial openness as the last independent variable of this research has a positive and significant effect on the amount of income gained from the tourism industry.

Therefore, in order to increase incomes from the tourism industry, the following offers are: 1)emphasize to enhance and improve the institutional ecosystem and governance with the emphasis on the six components of governance (control of corruption, efficiency and effectiveness of government, political stability and lack of violence (terrorism), the quality of legislation, rule of law and the right to comment and respond), the result of this estimations show in Appedix; 2) Emphasis on trade liberalization and reducing the depth of geopolitical and security in the country like Iran, because as long as the boundaries of a country are more open and the entry and exit will take place, this important causes the impact tourism revenues are, because when the arrival of tourists as a luxurious commodity will be facilitated within the boundaries of a country, it will increase the revenue that is gained from the tourism industry and grow And economic development is very influential; 
3) The emphasis on promoting GDP growth per capita, perhaps it can be analytic that the income of the country is directed towards the tourism industry, the fork of a single product economy fled, and on the other hand, any value in this is a more investment field, the tourism revenues of the next years, and consequently the revenue in the development of various sectors of the economy and thus the growth of production inside the country and Considering the results of this very eye-catching study, it can be used to increase tourism revenues; 4) At the end of the time, according to the results of six distinct model estimates for six sub-indicators of governance, by turning to the table, the results of the estimates were brought in the following, the right index of commenting and accountability, as well as the quality of the law and the highest estimation of the estimates of these seven overall models have been allocated. Special attention to this important outcome as well as the infrastructure for the promotion of these indicators can have a great impact on the increase of revenues gained from the tourism industry.

\subsection{Future suggestions to researchers}

Finally, the following research suggestions are provided for future studies by interested researchers: 1) Investigating the Impact of Network Readiness Index and Good Governance Index on Income from Tourism Industry (Case Study: OPEC and OECD Countries); 2) Investigate the impact of each of the Network Readiness Index and good governance subindicators on the amount of revenue from the tourism industry; 3) Investigating the Impact of Network Readiness Index and Good Governance Index on Income from Tourism Industry: A Nonlinear Approach.

\section{Appendix}

To create an overall indicator of good governance (based on the World Bank's metrics for this issue, they measure this with six key indicators for each country that are: (1. The right to speak and respond; 2. Political stability; 3. Government efficiency and effectiveness; 4. Quality of legislation; 5. Rule of law; and 6. Corruption control.) Identified and identified by the method of the principal components of the variance data used. Then by combining these factors the overall index is extracted. Software has been used for this method is SPSS.

To determine whether this method is suitable for combining the data used, the $\mathrm{KMO}^{1}$ test and the Bartlett test are used. The results can be as follows:

1) If the $\mathrm{KMO}$ is greater than 0.9 , then the factor analysis is very appropriate; 2 ) If the $\mathrm{KMO}$ is equal to 0.8 and smaller than 0.9 , it means that factor analysis is appropriate; 3 ) If the $\mathrm{KMO}$ is greater than 0.7 and smaller than 0.8 , then factor analysis is generally appropriate; 4) If $\mathrm{KMO}$ is greater than 0.6 and smaller than 0.7 , then factor analysis is generally not appropriate; 5) If KMO is less than 0.5, then factor analysis would not be appropriate at all (Arsh chi et al., 2013: 454). The results of this test are as follows (Table. 4).

Table 4. Results of the KMO and Bartlett Index for the Selected Countries

\begin{tabular}{ccc}
\hline $\begin{array}{c}\text { Kaiser-Meyer-Olkin Measure of Sampling } \\
\text { Adequacy }\end{array}$ & $\begin{array}{c}\text { Approx. Chi- } \\
\text { Square }\end{array}$ & 1543.342 \\
Bartlett's Test of Sphericity & Df. & 15 \\
\hline Resource: Research Findings & Sig. & 0.000 \\
\hline
\end{tabular}

${ }^{1}$ Kaiser-Meyer-Olkin Measure of Sampling Adequacy 
Also, According to (Table. 5) and the results, since the KMO index is 0.915 and is greater than 0.9 , then the combination of factors is very appropriate and this method can be used. Can be used to combine the data of the governance subsystems.

Table 5. Estimation of 7 separate models for examining the relationship of 4 subtypes of governance on tourism revenues

\begin{tabular}{|c|c|c|c|c|c|c|c|}
\hline \multicolumn{8}{|c|}{ Dependent variable: Natural logarithm of tourism industry revenue } \\
\hline $\begin{array}{c}\text { The } \\
\text { explanatory }\end{array}$ & 1 & 2 & 3 & 4 & 5 & 6 & 7 \\
\hline Cons & $\begin{array}{c}-71.758 \\
(0.000)\end{array}$ & $\begin{array}{c}-44.376 \\
(0.005)\end{array}$ & $\begin{array}{l}-63.967 \\
(0.000)\end{array}$ & $\begin{array}{c}-44.203 \\
(0.036)\end{array}$ & $\begin{array}{c}-62.529 \\
(0.000)\end{array}$ & $\begin{array}{c}0.404 \\
(0.987)\end{array}$ & $\begin{array}{c}-134.297 \\
(0.000)\end{array}$ \\
\hline NRI & $\begin{array}{c}1.345 \\
(0.033)\end{array}$ & $\begin{array}{l}-2.716 \\
(0.000)\end{array}$ & $\begin{array}{l}-1.473 \\
(0.060)\end{array}$ & $\begin{array}{l}-1.045 \\
(0.102)\end{array}$ & $\begin{array}{l}-2.634 \\
(0.000)\end{array}$ & $\begin{array}{c}4.908 \\
(0.000)\end{array}$ & $\begin{array}{c}1.439 \\
(0.621)\end{array}$ \\
\hline $\mathrm{Ln}$ (GDPP) & $\begin{array}{c}0.0004 \\
(0.000) \\
2.783 \\
(0.000)\end{array}$ & $\begin{array}{c}0.0001 \\
(0.172) \\
2.387 \\
(0.000)\end{array}$ & $\begin{array}{c}0.0003 \\
(0.000) \\
2.901 \\
(0.000)\end{array}$ & $\begin{array}{c}0.0007 \\
(0.596) \\
2.067 \\
(0.007)\end{array}$ & $\begin{array}{c}0.0001 \\
(0.238) \\
3.099 \\
(0.000)\end{array}$ & $\begin{array}{c}0.0005 \\
(0.000) \\
0.949 \\
(0.308)\end{array}$ & $\begin{array}{c}0.0004 \\
(0.001) \\
5.665 \\
(17.56)\end{array}$ \\
\hline Ln (TP) & $\begin{array}{c}0.239 \\
(0.014)\end{array}$ & $\begin{array}{l}-0.367 \\
(0.000)\end{array}$ & $\begin{array}{l}-0.146 \\
(0.417)\end{array}$ & $\begin{array}{l}-0.009 \\
(0.883)\end{array}$ & $\begin{array}{l}-0.368 \\
(0.022)\end{array}$ & $\begin{array}{l}-0.584 \\
(0.000)\end{array}$ & $\begin{array}{c}0.175 \\
(0.602)\end{array}$ \\
\hline Ln (TO) & $\begin{array}{c}0.246 \\
(0.020)\end{array}$ & $\begin{array}{c}0.381 \\
(0.000)\end{array}$ & $\begin{array}{c}0.140 \\
(0.200)\end{array}$ & $\begin{array}{c}0.118 \\
(0.406)\end{array}$ & $\begin{array}{c}0.235 \\
(0.126)\end{array}$ & $\begin{array}{c}0.057 \\
(0.725)\end{array}$ & $\begin{array}{c}0.041 \\
(0.240)\end{array}$ \\
\hline GGI & $\begin{array}{c}0.463 \\
(0.035)\end{array}$ & - & - & - & - & - & - \\
\hline $\mathrm{CC}$ & - & $\begin{array}{c}5.386 \\
(0.000)\end{array}$ & - & - & - & - & - \\
\hline GF & - & - & $\begin{array}{c}3.868 \\
(0.019)\end{array}$ & - & - & - & - \\
\hline PSAV & - & - & ( & $\begin{array}{c}2.474 \\
(0.000)\end{array}$ & - & - & - \\
\hline RQ & - & - & - & - & $\begin{array}{c}7.329 \\
(0.000)\end{array}$ & 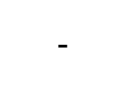 & - \\
\hline RL & - & - & - & - & - & $\begin{array}{c}9.879 \\
(0.000)\end{array}$ & - \\
\hline VA & - & - & - & - & - & - & $\begin{array}{c}9.819 \\
(0.000)\end{array}$ \\
\hline F-Statistics & $\begin{array}{c}14163 \\
(0.000)\end{array}$ & $\begin{array}{c}8408 \\
(0.000)\end{array}$ & $\begin{array}{c}25687 \\
(0.000)\end{array}$ & $\begin{array}{c}2535 \\
(0.000)\end{array}$ & $\begin{array}{c}8359 \\
(0.000)\end{array}$ & $\begin{array}{c}42817 \\
(0.000)\end{array}$ & $\begin{array}{c}11678 \\
(0.000)\end{array}$ \\
\hline $\begin{array}{c}\text { No.of } \\
\text { Observation }\end{array}$ & 84 & 84 & 84 & 84 & 84 & 84 & 84 \\
\hline No. Country & 14 & 14 & 14 & 14 & 14 & 14 & 14 \\
\hline
\end{tabular}

Reference: Research calculations

* The numbers in parentheses indicate the probability of the Z-Statistics and the numbers in the parentheses

\section{Acknowledgments}

The present article was extracted from the thesis written by Seyyed Mohammad Ghaem Zabihi and was financially supported by Ferdowsi University of Mashhad, Mashhad, Iran grants No. 51374. As well, the authors are grateful for the thoughtful and constructive comments provided by one the anonymous reviewers, which prompted significant improvements to the manuscript. 


\section{References}

[1] Aldebert, B., Dang R.J., and Longhi, C., "Innovation in the tourism industry: The case of Tourism", Tourism Management, 32(5), (2011), pp.1204-1213. DOI: 10.1016/j.tourman.2010.08.010.

[2] Altin, M.M. and Uysal, M., "Economic Sentiment Indicator as a demand determinant in tourism: A Case of Turkey”, (2011), Blacksburg, VA: Virginia Polytechnic Institute and State University.

[3] Arellno, M., Bond, S., "Same tests of specification for panel data, Monte Carlo evidence and an application to employment equations", The Review of Economic Studies, 58 (2), (1991), pp: 277 297. https://doi.org/10.2307/2297968

[4] Baltagi, B. H., "Econometric analysis of Panel Data". Chichester. John \& Sons Ltd. 3. Edition, (2005).

[5] Barnard, C. E., "Key drivers in environmental legislation towards Good govarance goerance", (2007). DOI: $10.2166 /$ wp.2007.128

[6] Blake, A., Sinclair, M.T., \& Campos Soria, J.A., "Tourism productivity: Evidence from the United Kingdom", Annals of Tourism Research, 33(4), (2006), pp:1099-1120. https://doi.org/10.1016/j.annals.2006.06.001

[7] Bovaird, T., "Beyon engagement and participation - user and community co-production of public services", Public Administration Review, 67 (5), (2007), pp:846-860. https://doi.org/10.1111/j.15406210.2007.00773.x

[8] Buhalis, D, Deimezi, O., "E-tourism Development in Greece: Informaion Communication Technologies Adoptin For the Strategic Managment of the Gveece Tourism Industry", Tourism and Hospitaly Research, 5(2), (2004), pp: 103-130. https://doi.org/10.1057/palgrave.thr.6040011

[9] Boga, Semra., Erkisi, Kemal., "The relationship between international tourism receipts and Economic Growth in asia pacific countries: A panel Data Analysis”. Akademik Hassasiyetler, 6(11), (2019).

[10] Byrd, T.A., \& Marshall, T.E., "Relating information technology investment to organizational performance: a causal model analysis", OMEGA International Journal of Management Science, 25(1), (1997), pp: 43-56. https://doi.org/10.1016/S0305-0483(96)00040-0.

[11] Cornelissen, S., “The Global Tourism System: Governance, Development and Lessons from South Africa", Retrieved from: http://books.google.com/books?id=lx6dOKGZKAoC\&printsec=frontcover \&dq=Cornelissen, + S. +( 2005).+The+Global+Tourism+System:+Governance,+Development+and+Lessons+from+South+A frica.\&hl=en\&ei=VKXOTcCxM4SfQa48qXXBw\&sa=X\&oi=book_result\&ct=result\&resnum=1\& ved=0CCkQ6AEwA\#v=onepage \&q\&f=f alse , (2005).

[12] Coopers, C., Fletchair, J., “Tourism Principles and Practices”, Pearson, UK., (2005).

[13] Cox, C., Burgess, S., Sellito, C., and Buultjens, J. , “The Role of User Generated Content in Tourists' Travel Planning Behaviour", Journal of Hospitality Marketing and Management, 18(8), (2009), pp: 743-764. https://doi.org/10.1080/19368620903235753.

[14] Cho, V., "A study of the non-economic determinants in tourism demand", International Journal of Tourism Research, 12(4), (2010), pp: 307-320. https://doi.org/10.1002/jtr.749.

[15] Daryaei, Abbasali., Aliashrafipour, Mohammad., \& Eisapour, kamal.,\& Afshaian, Mojtaba., "the effect of good governace on tourism industry development", Advances in environmental biology, 6(7), (2012), pp: 2046-2052. 
[16] Ershi Qi, Jiang Shen, Runliang Dou., "Proceedings of 20th International Conference on Industrial Engineering and Management: Theory and Apply of Industrial Management”, Springer Science \& Business Media, (2013).

[17] Global Telecommunication Union Report, (2013), Retrieved May 11, (2020), From: https://www.google.com/url?sa=t\&rct=j\&q=\&esrc=s\&source=web\&cd=\&cad=rja\&uact=8\&ved=2 ahUKEwibrMvCn_TpAhXJi6QKHWjXAYUQFjAAegQIAhAB\&url=https\%3A\%2F\%2Fwww.itu .int $\% 2$ Fen $\% 2$ FITU-

D\%2FStatistics\%2FDocuments\%2Fpublications\%2Fmis2013\%2FMIS2013_without_Annex_4.pdf \&usg=AOvVaw2ZDmiQSTz5AK_U3NG-mACA

[18] Ghulam Ali , Kalid zaman., Talat Islam., "Macroeconomic Shocks and Malaysian tourism Industry: Evidence from a Structural VAR Models”, Iran. Eco. Rev, 22(4), (2018), pp: 1113-11370. DOI: 10.22059/ier.2018.67878.

[19] Gomis, Joan Miquel, and Francesc González-Reverté., “Amadeus: global distribution system’s new paradigm", eTourism Case Studies, 399, (2012).

[20] Gruescu, R., Nanu, R., and Pirvu, G., "Information and Communications Technology and Internet Adoption Tourism", Bulletin UASVM Horticulture, 66(2), (2009), pp: 407-413.

[21] Gratzer, M., Werthner, H., \& Winiwarter, W., "Electronic business in tourism”, International Journal Electronic Business, 2(5), (2004), pp: 450-459. DOI: 10.1504/IJEB.2004.005878.

[22] Hansen, Lars Peter., "Large Sample Properties of Generalized Method of Moments Estimators", Econometrica, 50(4), (1982), pp:1029-1054. http://www.jstor.org/stable/1912775.

[23] Hall, C.M., "Tourism Planning: Policies, Processes and Relationships", Harlow Pearson, Education Ltd, (2000).

[24] Hipp, C., \& Grupp, H., "Innovation in the service sector: the demand for service specific innovation measurement concepts and typologies", Research Policy, 34, (2005), pp: 517-535. DOI: 10.1016/j.respol.2005.03.002.

[25] Irvine, A., \& Anderson, A.R., "ICT (information communication technology), peripherality and smaller hospitality businesses in Scotland", International Journal of Entrepreneurial Behaviour \& Research, 14(4), (2008), pp: 200-218. DOI: 10.1108/13552550810887381.

[26] Kuttainen, C. and Lexhagen, M., "Overcoming Barriers to Sme E-Commerce Adoption using Blended Learning: A Swedish Action Research Case Study”, Information Technology \& Tourism, 13(1), (2012), pp: 13-26. DOI: 10.3727/109830511X13167968595660.

[27] Leitão, Alexandra., "Corruption and the Environmental Kuznets Curve: Empirical Evidence for Sulfur", Universidade Nova de Lisboa, CEGE, Rua Diogo Botelho, 1327, PT-4169-005, (2006). DOI: $10.1016 /$ j.ecolecon.2010.06.004.

[28] Leitão, Nuno Carlos., "Portuguese Tourism Demand: A Dynamic Panel Data Analysis", International journal of economics and financial issues, 5(3), (2015), pp: 673-677. Availabel at https://www.econjournals.com.

[29] Michael J. Panik., “Growth Curve Modeling: Theory and Applications”. ISBN: 978-1-118-76404-6. 454 Pages, (2015).

[30] Mamipour, Siab., Nazari, Kaveh., "The Contribution of Tourism Development To Economic Growth in the Iranian Provinces”, journal of inernational Economic and Managment Studies, 1(11), (2014), pp: 99-120. https://doi.org/10.1016/j.fbj.2018.09.001.

[31] Marcussen, C., "Internet Distribution of European Travel and Tourism Services", Research Centre of Bornholm, Denmark, (1999). DOI: 10.1002/jtr.319. 
[32] Mupfiga,. "Adoption of ICT in the Tourism and Hospitality Sector in Zimbabwe", The International Journal of Engineering and Science (IJES), 4(12), (2015), pp: 72-78.

[33] Martin, L.M., “E-innovation: Internet impacts on small UK hospitality firms”, International Journal of Contemporary Hospitality Management, 16(2), (2004), pp: $\quad 82-90$. https://doi.org/10.1108/09596110410519964

[34] Minghetti, V., \& Buhalis, D., “Digital Divide in Tourism”, Journal of Travel Research, 49(3), (2010), pp: 267-281. DOI: 10.1177/0047287509346843.

[35] Peppard, J., "IT Strategies for Business”, London: Pitman Publishing, (1993).

[36] Poon, A., “Tourism, Technology and Competitive Strategies” Oxford: CAB International, (1993).

[37] Show, G., Williams. A., “Tourism and Tourism spaces”, London, stage, (2004).

[38] Stiakakis, E., Georgiadis, Ch.K., "Drivers of a Tourism e-business Srategy: The Impact of Information and Communication Technologies", Operational Research, 11(2), (2011), pp: 149-169. DOI: 10.1007/s12351-009-0046-6.

[39] Suomi, R., and Li, H., "Internet Adoption in Tourism Industry in China", IFIP International Federation for Information Processing, 286(1), (2010). DOI: 10.1007/978-0-387-85691-9_17.

[40] UNCTAD, (2004), UNCTAD'S eTourism Initiative, Doc. TD (XI)/BP/6), 26 April. Retrieved October 11, 2018 from: http://www.unctad.org/en/docs/tdxipbd6_en.pdf.

[41] Werthner, H. and Klein, S., "Information Technology and Tourism - A Challenging Relationship", New York: Springer, (1999).

[42] Tahayori, H., \& Moharrer, M., "E-Tourism: The Role of ICT in Tourism Industry, Innovations and Challenges", Retrieved May 11, (2010), from http://www.scribd.com/doc/7113770/Tourism-TheRole-of-ICT-in-Tourism-Industry-Innovations-and-Challenges.

[43] The Report of Ict from World Economic Fourm report, Retrieved May 11, (2020), from https://www.google.com/url?sa=t\&rct=j\&q=\&esrc=s\&source=web\&cd=\&cad=rja\&uact=8\&ved=2 ahUKEwjgpuvrnvTpAhXKGuwKHfsfA5gQFjAAegQIBRAB\&url=http\%3A\%2F\%2Fwww3.wefo rum.org\%2Fdocs\%2FWEF_GITR_Report_2013.pdf\&usg=AOvVaw1HJzL6pfr-ph4uIDIqbzgA, (2013).

[44] United Nations World Tourism Organization (UNWTO), "UNWTO Tourism Highlights (2011)". Madrid: UNWTO, (2011).

[45] Xiaoqiu Ma, J., Buhalis, D., \& Song, H., "ICTs and Internet adoption in China's tourism industry", International Journal of Information Management, 23(6), (2003), pp: 451-467.

[46] Zhou, Z., "E-commerce and information technology in hospitality and tourism", New York: Delmar Publishing, (2004). 


\section{Authors}

Seyyed Mohammad Ghaem Zabihi, MSC student of Economics, Ferdowsi University of Mashhad, Mashhad, Iran.Smq.Zabihi@mail.um.ac.ir

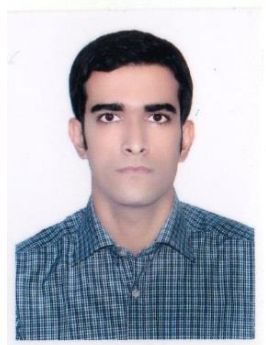

Mahmoud Hooshmand*, Corresponding Author: Professor of Economics, Ferdowsi University of Mashhad, Mashhad, Iran. M-Hoshmand@um.ac.ir

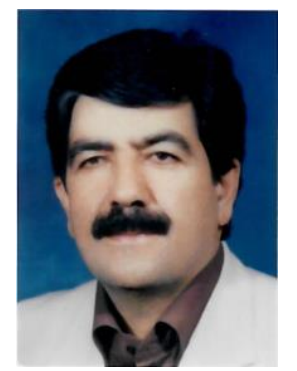

Narges Salehnia, Assistant Professor of Economics, Ferdowsi University of Mashhad, Mashhad, Iran. N.Salehnia@um.ac.ir 